\title{
上顎洞にみられた嵿動脈外傷性動脈瘤
}

\author{
鈴木 慎二1) ・ 木村 有一2) ・ 金地 明星 ${ }^{3)}$ \\ 須藤 正治 ${ }^{1)} \cdot$ 五十嵐 充 ${ }^{4)} \cdot$ 山本 英之 ${ }^{1)}$

\section{Traumatic Maxillary Artery Aneurysm with Rupture into the Maxillary Sinus}

\author{
Shinji Suzuki, Masaharu Sudo and Hideyuki Yamamoto \\ (Fukui Red Cross Hospital) \\ Yuichi Kimura \\ (Fukui Medical School) \\ Myojo Kanaji \\ (Kanaji Clinic) \\ Mitsuru Igarashi \\ (Osaka Daiichi Hospital)
}

\begin{abstract}
A case of traumatic aneurysm was reported. A 25-year-old man was admitted to our hospital with severe epistaxis and oral hemorrhage caused by a fall. Multiple maxillofacial fractures were found by CT. Nasal packing for the epistaxis and reduction of the fractured mandible were immediately performed. The patient seemed to be doing well; however, epistaxis reoccured 13 days after the injury. Nasal packing was not effective for the recurrent bleeding.

To confirm the bleeding site, angiography by the Seldinger technique was performed. Angiography demonstrated the presence of an aneurysm in the area of the left maxillary artery. Therefore, superselective embolization using microcoils was performed. After this procedure, epistaxis was completely controlled.
\end{abstract}

Key words : traumatic aneurysm, epistaxis, superselective embolization

\section{はじめに}

外傷性動脈瘤は骨折や切創などの外傷による動脈損傷 を原因として種々の部位に括いて発生し得る．実際，脳 神経外科や整形外科領域での報告は多いが，耳鼻咽喉科 領域に扮ける外傷性動脈瘤の報告は少ない，今回我々は， 顎顔面多発骨折後に大量の鼻出血を繰り返した顎動脈領 域の外傷性動脈瘤に対し, 超選択的塞栓術を試み良好な 結果を得たので, 若干の文献的考察を加兄て報告する.

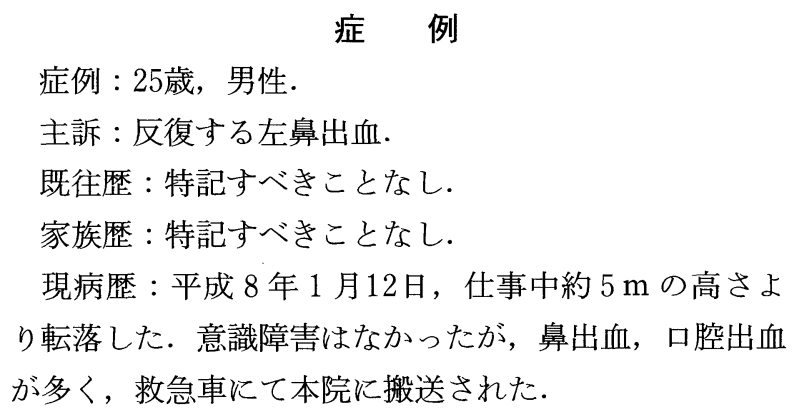

1）福井赤十字病院耳鼻咽喉科

2）福井医科大学耳鼻咽喉科学教室

3）かなじ耳鼻咽喉科（滋賀県甲賀郡）

4）大阪第一病院耳鼻咽喉科 
初䛦時所見 : 左鼻出血, 口腔裂傷に伴ら出血を認めた ため，それぞれ鼻腔内圧迫タンポン挿入抌よびロ腔縫合 処置にて止血した。また，咽頭浮腫による上気道狭窄を 伴っていたため, 経鼻插管を行った。气他の全身の異 常として左前腕骨折を認めたため，ギブス固定を行った，

経過：CT 検查にて下顎骨折(図 1) と上顎の多発骨折 （図 2 ）が判明したため，当院口腔外科の協力を得てただ ちに口内法による下顎骨折整復を行った．上顎骨折につ いては大きな偏位がないため，保存的に経過をみること とした。1月14日に抜管し，咬合不整に対して 1 月19日 に顎間固定を開始した。その後順調に回復していたが， 受傷後13日目に左鼻出血をさたした。そのとき，左鼻腔 内は凝血塊で充満して打り, 凝血塊を除去した後鼻腔内 を観察するるすで出血は止まっており，鼻中隔，中鼻 甲介，下鼻甲介粘膜の発赤特よび充血は認められず出血 部位は不明であった。しかし，出血量がやや多めであっ たため，出血防止の目的も兼水鼻腔内に圧迫タンポンを 挿入した。 その後タンポン抜去するも，何度となく鼻出 血をきたし，その都度圧迫タンポンを挿入し，全身的に は止血剤を投与した。受傷後20日目に再度大量の鼻出血

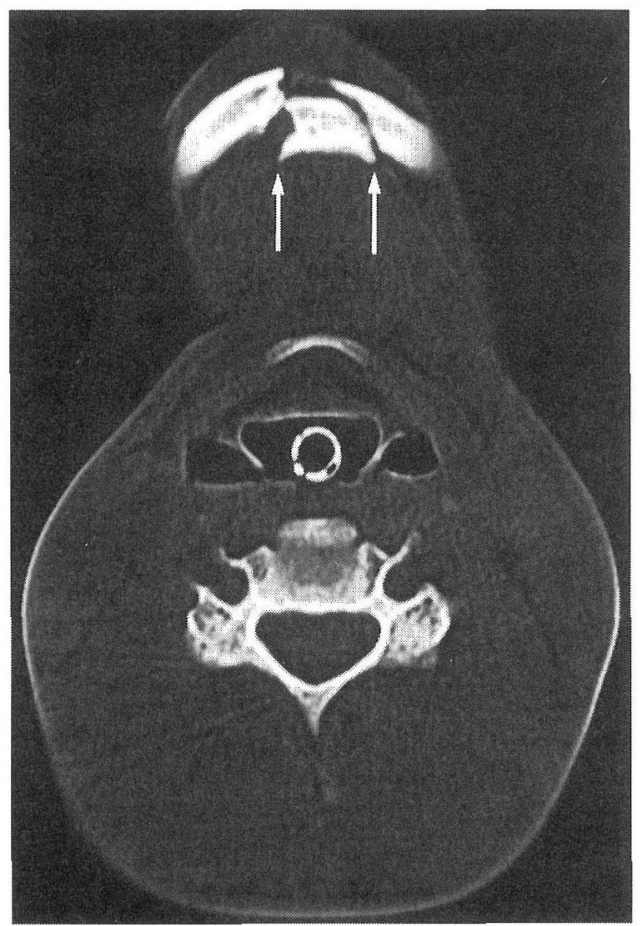

図 1 受傷当日の CT 所見 下顮骨折 (矢印)が認められる。

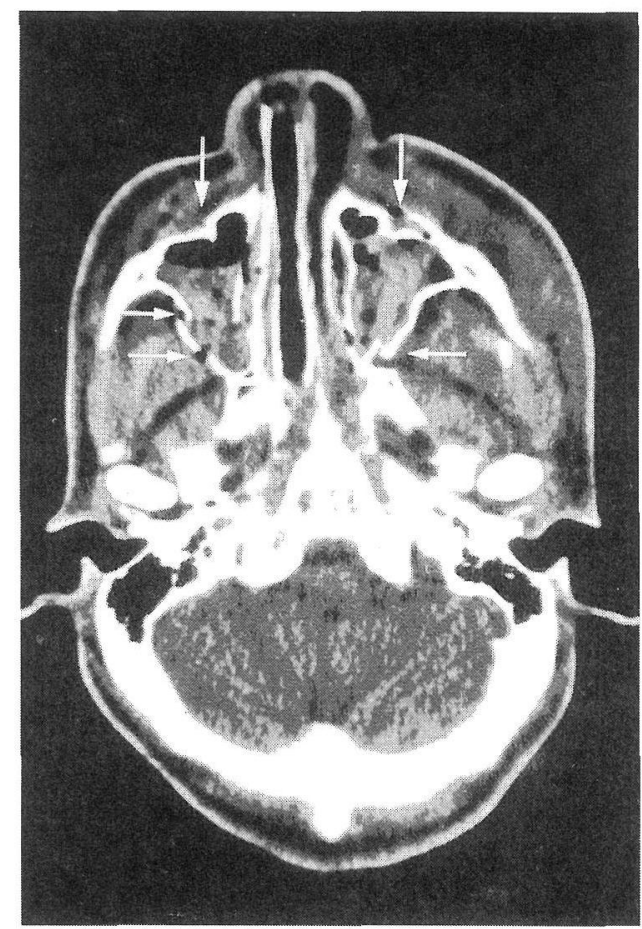

図 2 受傷当日の CT 所見

上䋶の多発骨折 (矢印) が認められる. 右鼻腔内には扱管 チューブが留置されている。

をきたし，そのとき中鼻道に限局して凝血塊が付着して 拈り，上買洞からの出血と思われたため再度 $\mathrm{CT}$ 検查施 行した. CT では左上顎洞内はやや高輝度の物質が充満 して挆り，出血点ははっきりしなかった(図 3 )。そこで 出血点の確認と可能であれば塞栓による止血を行うこと を目的として，当院脳外科飞依頼して 2 月 27 日飞血管撮 影を行った。

6 フレンチのカテーテル挿入をセルディンガー法で大 腿動脈より行い，左外頸動脈より顎動脈進め造影剤の 注入をしたところ，左上䫟洞内に $2.0 \times 2.5 \mathrm{~cm}$ の動脈 瘤を確認した（図４）。そこでプラチナ性の金属コイルを 5 本使用して動脈瘤の塞栓術を施行した. 塞栓後の血管 造影では流入動脈内に金属コイルが插入されて招り，動 脈瘤への血流遮断を認めた(図 5 )。攵の後は経過良好で 再出血は認めていない。

また，顎間固定と開口訓練により受傷 3 カ月後には咬 合不全，開口障害は認められなくなった。 


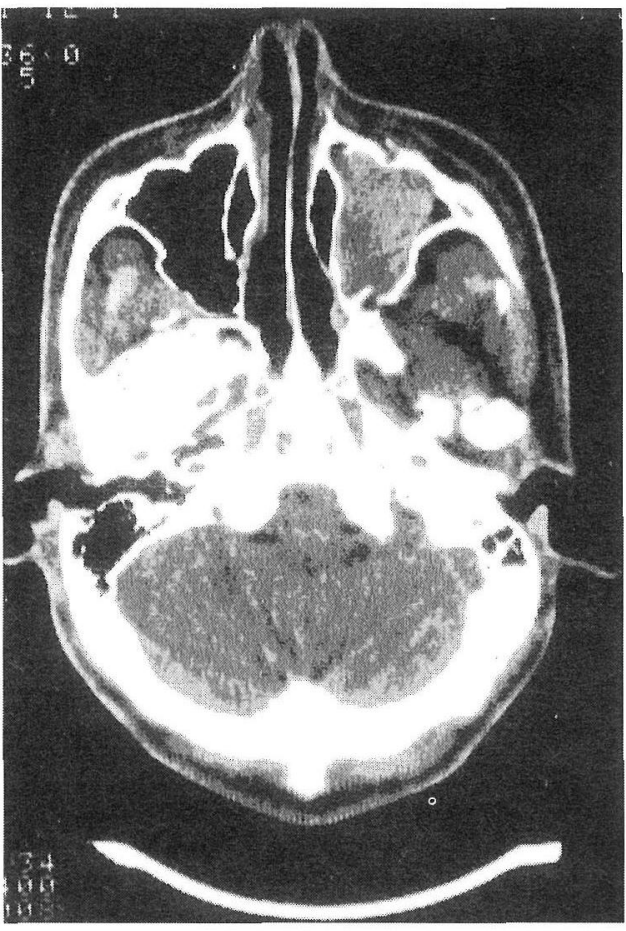

図 3 受傷後33日目の CT 所見

\section{考察}

外傷性動脈瘤は遅発性に出血をきたしやすく, 早期の 根治的治療が必要な疾患であるが，その診断はしばしば 困難で，外傷後一定期間を経てから動脈瘤の破裂により

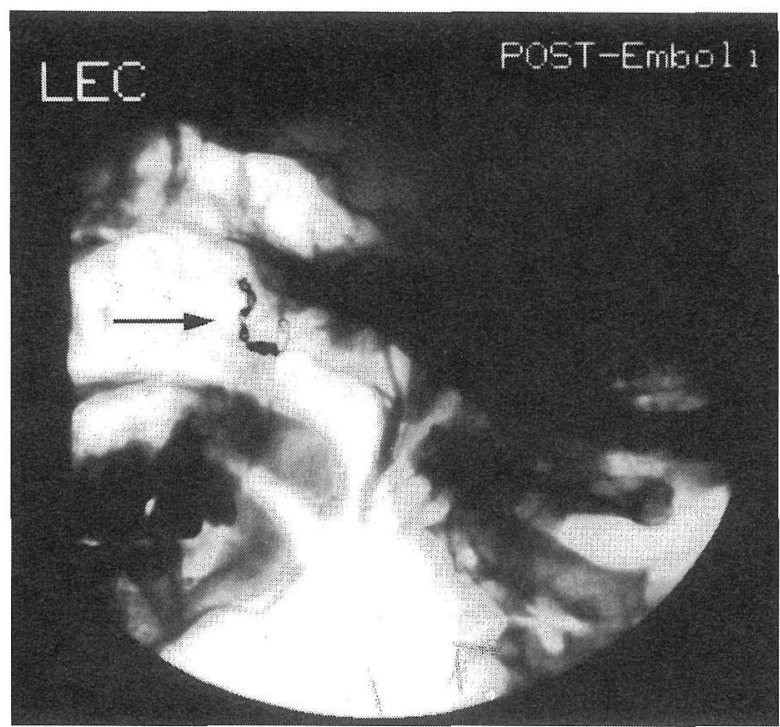

図 5 塞检後の左外頸動脈造影

流入動脈内に金属コイル(矢印)が挿入されている.

はじめて発見されることが多く, 破裂前に診断されるこ とは少ない1)。

病理組織学的には, 動脈瘤壁に血管の構成成分を認め ない偽性動脈瘤と動脈瘤壁が血管外膜で構成される真性 動脈瘤とに分類されるが，前者の方が多く骨折や切傷後 に生じ，後者はまれであるが慢性的な機械的刺激により 生じるといわれている. 本症例は, 病理組織学的な確認

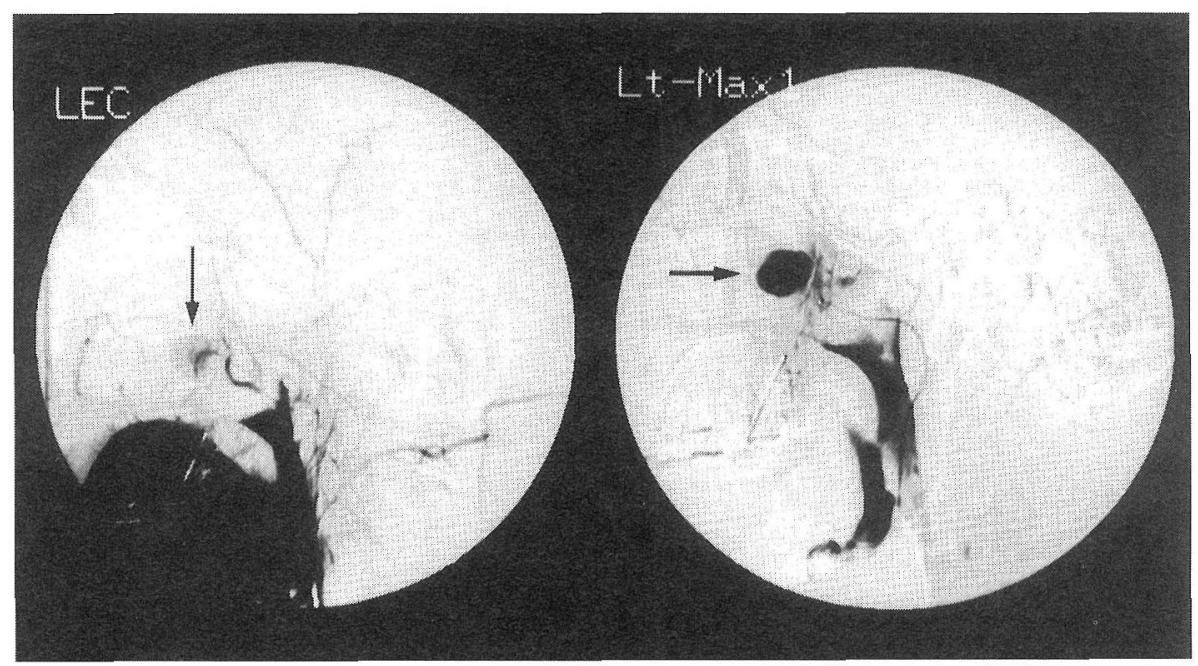

図 4 左 : 左外頸動脈造影にて顎動脈領域に動脈瘤(矢印) を認める.

右：顎動脈より造影剂を注入すると上顎洞内に動脈瘤(矢印)が認められた。 
は行っていないが，括そらく偽性動脈瘤であったと思わ れる. 偽性動脈瘤の発生のメカニズムとしては, 不完全 断裂の形で動脈の血管壁全層が損傷を受け，早期にはそ の断裂部周囲に血腫を生じるが，その後血腫内には凝固 器質化した被膜様組織が生じ, 動脈瘤内部に徐々に血液 が漏出することで動脈瘤内圧は上昇し径は増大する。そ して, 数週間で壁内部には内皮細胞が出現し, 壁は線維 性症痕に変化して形成される2). 真性動脈瘤の場合は血 管壁の内膜や中膜が損傷を受けて血管壁が引き伸ばされ て形成されるが，動脈瘤壁は血管外膜で構成される。な かでも岩橋引の実験的研究では, 動脈瘤発生には特に中 膜の外弾性板の変化が重要な条件で, その変化の大きさ が動脈瘤の拡大度と比例するという，外傷性動脈瘤の破 裂しやすい時期としては受傷後 10 日〜 2 週間前後が多い といわれているが4)，本症例も同時期に発症している. 経時的变化としては徐々に拡大寸ることが多いが，時に 自然に閉塞することもあるといわれている4).

診断には血管撮影が有用で, 親動脈が外頸動脈系であ れば同時に塞栓術にて治療することができる。一般に塞 栓術は外科的侵襲が少ない, 造影にて血管の異常や出血 点が確認できる, 選択的な血流遮断ができる, 緊急時に も施行可能であるなどの利点があるが，内頸動脈領域塞 栓症の合併の危険性や内頸動脈領域の出血飞対応できな いといら久点がある．塞栓物質として本症例では，永続 的な塞栓が期待でき, 塞栓子が大循環へ流出しにくく内 頸動脈領域の塞栓症の合併の可能性が少ない金属コイ ル5) 7) を使用した．塞栓術以外の治療法としては, 動脈 瘤の完全切除, 動脈瘤茎部の結紮またはクリッピング, 動脈瘤の両側で親動脈をクリッピングするトラッピング, 親動脈の結禁などがあるが, 症例に応じて治療法を選択 する必要がある。

塞栓術が普及するまでは, 本症例のような場合は顎動 脈あるいは外頸動脈の結紮を行っていたと思われるが，
その当時は出血部位の確認のための血管撮影を行うこと も少なく，術前に動脈瘤の診断を得る機会が少なかった と思われる。それが，耳鼻咽喉科領域に执いて現在まで 外傷性動脈瘤の報告が少ない一因と考学られる.

\section{まとめ}

1. 顎動脈領域に発生した外傷性動脈瘤の一例を報告 した.

2. 診断には血管撮影が有用であり，同時に超選択的 に塞栓術を行い良好な結果を得た。

3. 骨折を伴ら外傷後に遅発性に出血を繰り返す場合 は, 動脈瘤を形成している可能性があると思われた.

\section{参考文献}

1) 関野宏明: 外傷性脳血管障害. 脳神経外科 Quick Reference 一合理的な診断と治療一(関野宏明, 佐藤 潔, 山浦 晶編). 109 122頁, 文光堂, 東京, 1989.

2 ）城崎和久, 矢島弘嗣, 赤羽 学, 他: 前腕に批ける外傷性 偽性動脈瘤. 中部整災誌 $39: 257 \sim 258,1996$.

3 ）岩橋 勲: 血栓並びそ動脈瘤形成に関する実験的研究. 名 古屋医学 $69: 1091 \sim 1111,1955$.

4 ）坪川孝志, 小谷昭夫, 菅原武仁, 他 : 末梢型外傷性動脈瘤 の増悪型と自然治癒型. 脳外 $3: 663 \sim 672,1975$.

5 ) 高橋元一郎 : 頭頸部の塞栓療法. IVR の臨床 (高橋睦正, 山下康行編). 85 102頁, 朝倉書店, 東京, 1995.

6 ) 滝 和郎, 半田 肇: 頭頸部領域の人工塞栓術. 脳外 11 : $7 \sim 15,1983$.

7 ）米川泰弘, 滝 和郎, 石川正恒, 他 : 頭頸部血管の人工塞 栓術. 外科治療 $49: 273 \sim 284,1983$.

$$
\left(\begin{array}{l}
\text { 原稿受付 : 平成 } 11 \text { 年 } 3 \text { 月 } 18 \text { 日 } \\
\text { 原稿採択 : 平成 } 11 \text { 年 } 4 \text { 月 } 28 \text { 日 } \\
\text { 別刷請求先 : 鈴木慎二 } \\
\text { 厂 } 918-8501 \text { 福井市月見 } 2-4-1 \\
\text { 福井赤十字病院耳鼻咽喉科 }
\end{array}\right)
$$

